\title{
Rice Beetle, Dyscinetus morator (Fab.) (Insecta: Coleoptera: Scarabaeidae) 1
}

R. E. Woodruff ${ }^{2}$

\section{Introduction}

The rice beetle, Dyscinetus morator, is a common beetle in the eastern half of the U.S. and is one of the most ubiquitous species taken in blacklight traps during much of the year. It appears to be only a minor pest, but it is often brought to the homeowner's attention because of the large quantities found at lights.

\section{Taxonomy}

Dyscinetus is a member of the subfamily Dynastinae and the tribe Cyclocephalini. Blackwelder (1944) listed 22 species in this exclusively American genus. Casey (1915) divided the genus into two groups based on the presence of absence of sexual dimorphism in the anterior tarsi. Only two species are recognized from the U.S. by Saylor (1945): $D$. picipes (Burm.) from the southwestern U.S., Mexico, and the West Indies, and D. morator (Fab.) from the eastern U.S. west to Texas. The latter was known for many years as $D$. trachypygus (Burm.). Both species are highly variable and have several synonyms described primarily by Casey (1915). Although Saylor synonymized all of Casey's species and implied he had examined the genitalia of the types,
Blackwelder and Blackwelder (1948) stated, "Less than a third of the holotypes (or species) have been dissected by anyone. Since Saylor states that 'it is necessary to dissect and compare the male genitalia in order properly to place many of the troublesome variants,' his synonymy must be considered as inconclusive."

\section{Distribution}

It appears to be found in most of the eastern U.S., although much more abundant in the south. It is present throughout Florida, including the northern Keys. It is found west as far as Texas, Oklahoma, Kansas, and Iowa.

\section{Description}

\section{Adult}

The length of the adult is $1 / 2$ to $3 / 4$ inch, while the width is $5 / 16$ to $7 / 16$ inch. This is an extremely variable species in size, color, and shape. The rice beetle is usually black with a slight green sheen; oblong, subparallel, and moderately convex. Elytral punctures form five costules (ridges), their bordering punctures nearly parallel, intervals nearly impunctate, the remaining punctures irregular and

1. This document is EENY-102, one of a series of the Entomology and Nematology Department, Florida Cooperative Extension Service, Institute of Food and Agricultural Sciences, University of Florida. Original publication date July 1999. Reviewed May 2003. Visit the EDIS Web Site at http://edis.ifas.ufl.edu. 2. R.E. Woodruff, Florida Department of Agriculture and Consumer Services, Division of Plant Industry, Gainesville, FL.

The Institute of Food and Agricultural Sciences (IFAS) is an Equal Opportunity Institution authorized to provide research, educational information and other services only to individuals and institutions that function with non-discrimination with respect to race, creed, color, religion, age, disability, sex, sexual orientation, marital status, national origin, political opinions or affiliations. U.S. Department of Agriculture, Cooperative Extension Service, University of Florida, IFAS, Florida A. \& M. University Cooperative Extension Program, and Boards of County Commissioners Cooperating. Larry Arrington, Dean 
variable. The male has the last tarsal segment of the anterior tarsi enlarged and the terminal claws unequal in size, while the female has normal anterior tarsi with the claws equal.

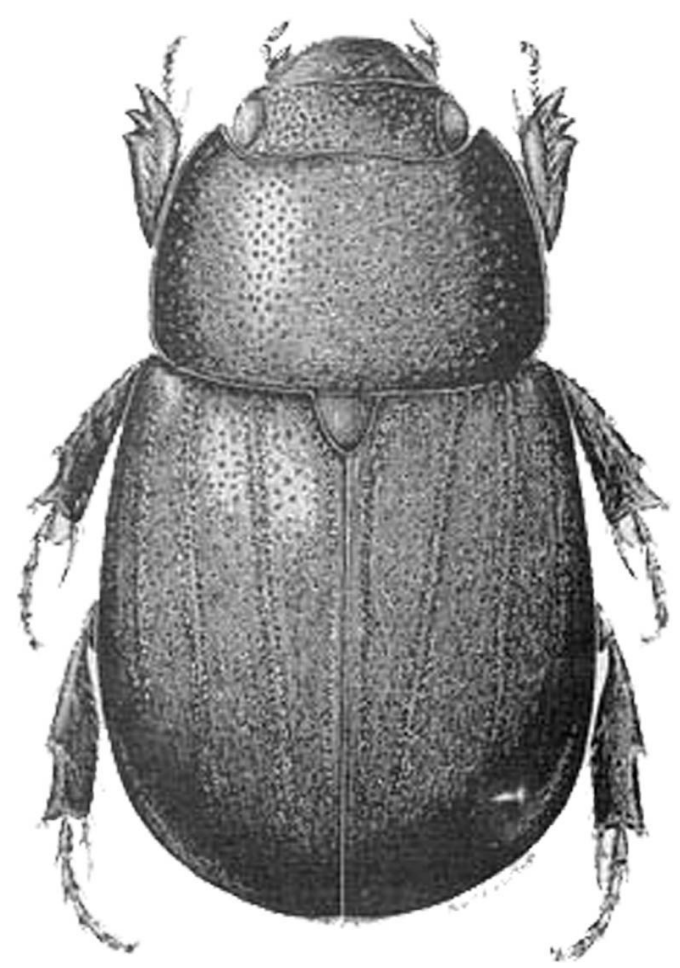

Figure 1. Adult male rice beetle, Dyscinetus morator (Fab.). Credits: Paul. M. Choate, University of Florida

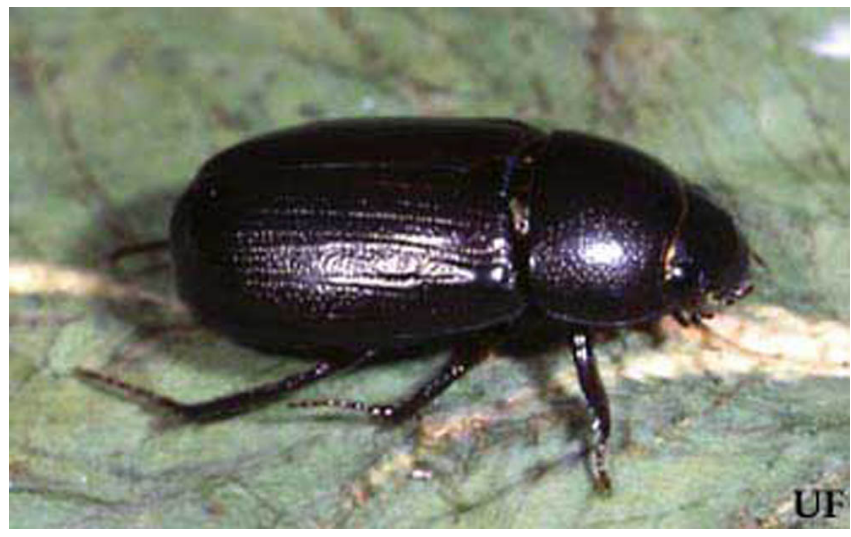

Figure 2. Adult rice beetle, Dyscinetus morator (Fab.). Credits: Paul. M. Choate, University of Florida

\section{Larva}

The larva is a typical C-shaped scarab "white grub." Detailed descriptions can be found in Phillips and Fox (1924) and Ritcher (1944). The larva is easily distinguished from that of the related
Euetheola by the absence of a median row of modified bristles on the last ventral segment (raster).

\section{Biology}

There have been very few observations on the details of the life history and behavior of this species. Phillips and Fox (1942) indicated that the life history agrees closely with Euetheola rugiceps (the rough-headed corn stalk-borer), but Dyscinetus appears to be more tolerant of the products of organic putrefaction (e.g., compost heaps and near pig pens). They found no evidence that it injures corn, but stated, "Farther south they attack rice, and for that reason the species has been given the popular name of 'rice beetle'." I have been unable to find any additional references to this habit in the United States; however, another species, D. gagates (Burm.), is known as "escarabajo negro del trigo" in Argentina (Bosq 1945).

The adults are nocturnal and attracted to lights, especially ultraviolet (blacklight) and mercury vapor. They are especially abundant where such lights are placed near natural areas for the first time (e.g., in subdivisions, trailer lots, and newly cleared land). Such a situation occurred at Sebring, Florida, where bushels of the beetles were collected around nearly erected light posts in a scrub oak-sand pine area. Once they are attracted to a light, they stay until dawn, when the daylight forces them to look for shelter (usually burrowing under any convenient shelter or into the soil). The same process is repeated each night, creating large numbers of beetles around a single light post.

There appear to be two generations per year in Florida, at least in the southern portion, judging from the large adult population peaks in the spring (March) and fall (November). Hays (1925) stated, "Others of the subfamily known to require the same, or approximately the same time [one year], are ... Dyscinetus trachypygus, Dyscinetus barbatus, and Euetheola rugiceps." Smyth (1915) studied the life cycles of two species (D. trachypygus and $D$. barbatus) in Puerto Rico. Although there is a possibility of misidentification, D. morator (=trachypygus) is not now thought to be in the West 
Indies). Smytrh found the average complete cycle from egg to adult was 104 and 144 days, respectively.

\section{Economic Importance}

Although this species often has been suggested as a pest of several crops, little incriminating evidence is available. Scammell (1917:42) listed it, along with two other scarabs, as a pest in the larval stage of cranberries in New England. The statement above relating to rice feeding is probably the result of taxonomic confusion. Other South American species are listed as pests of sugarcane, forests, and potatoes. In Highlands County, Florida, commercial growers consider it a pest of caladium bulbs in the field. Adult beetles often have been found associated with caladium bulbs and slight injury, but no direct feeding observations have been made. In at least one case, after installation of mercury vapor lights, thousands of beetles were attracted to the area and the vegetation around the poles was often killed. It has not been determined if this is the results from feeding on the roots, from aeration of the soil by burrowing, or from the toxic effects of body fluids leaching from the great quantity of dead beetles on the surface. I suspect that it may be a combination of the latter two factors.

\section{Management}

There have been no insecticidal tests conducted specifically against this beetle or its larva. Flooding has been recommended as a possible control in certain marshy situations where the crop schedule will permit. Thousands of the beetles can be collected at lights, and it has been recommended that traps be used in conjunction with these lights. A pan or bucket of soapy water suspended below a light has been used for control of May beetles and relatives. This system, with improved ultraviolet as an attractant, is still very effective in collecting large numbers of beetles.

No effective parasites or predators are known, although Moss and Funk (1965) described a new genus and species of mite, Dyscinetonyssus hystricosus, from beneath the elytra of Dyscinetus from Highlands Hammock State Park, Florida, collected in April 1962. They suggest that it is parasitic, although no behavioral observations were made on living material. Natural controls are not known although milky disease, as used for Japanese beetle control, is a possibility. Birds and other predators do not appear to eat the beetles even when there are thousands dead and dying in an area.

\section{Selected References}

Blackwelder, R.E. 1944. Checklist of the coleopterous insects of Mexico, Central America, the West Indies, and South America. U.S. Natl. Mus. Bull. 185: 189-341.

Blackwelder, R.E., and R.M. Blackwelder. 1948. Fifth supplement, 1939 to 1947 (inclusive), to the Leng catalogue of Coleoptera of America, north of Mexico. John D. Sherman, Jr., Mt. Vernon, N.Y. 87 p.

Bosq, J.M. 1945. El "escarabajo negro del trigo" [Dyscinetus gagates] puede ser daino a la silvi-cultura. Argentina Min. de Agr. Almanaque (1945) 20: 65-67.

Casey, J.L. 1915. A review of the American species of Rutelinae, Dynastinae and Cetoniinae, $p$. 1-394. In Memoirs of the Coleoptera VI. New Era Printing Co., Lancaster, PA. 460 p.

Davis, J.J. 1916. A progress report on white grub investigations. J. Econ. Ent. 9: 261-281; 3 p.

Hayes, W.P. 1925. A comparative study of the history of certain phytophagous scarabaeid beetles. Kansas Agr. Exp. Sta. Tech. Bull. 16: 1-146.

Koehler, P.G., D.E.Short and T.R. Fasulo. (1998). Pests In and Around the Home. UF/IFAS SW-126. CD-ROM.

Moss, W.W., and R.C. Funk. 1965. Studies on the developmental chaetotaxy of Dyscinetonyssus hystricosus n.g., n.sp. (Acari: Mesostigmata: Laelaptoidea). Acarologia 7: 235-267.

Phillips, W.J., and Henry Fox. 1924. The rough-headed corn stalk-beetle. USDA Dept. Bull. 1267: 1-34.

Ritcher, P.O. 1944. Dynastinae of North America with descriptions of the larvae and keys to 
the genera and species (Coleoptera: Scarabaeidae).

Kentucky Agr. Exp. Sta. Bull. 467: 1-56.

Saylor, L.W. 1945. Synoptic revision of the

United States scarab beetles of the subfamily

Dynastinae, No. 1, tribe Cyclocephalini. J.

Washington Acad. Sci. 35: 378-386.

Scammell, H.B. 1917. Cranberry insect problems and suggestions for solving them. USDA Farmers' Bull. 860: 1-42.

Smyth, E.G. 1915. Report of the south coast laboratory. 4th Rept. Board Comm. Agr. Puerto Rico (July 1914-June 1915): 45-50. 